\title{
Indirect Speech Strategies and Their Application Areas
}

\author{
Elena Nikitina ${ }^{1}$ \\ ${ }^{1}$ Institute of Linguistics, RAS \\ Correspondence: Elena Nikitina, Institute of Linguistics, RAS. E-mail: m1253076@yandex.ru
}

Received: November 17, 2019; Accepted: December 24, 2019; Published: December 28, 2019

\begin{abstract}
The effectiveness of speech tactics is a direct derivative of the degree of creative activity of the listener. Creative thinking has an analogous nature - the convergence of objects and concepts, not amenable to convergence outside of the rhetorical situation. Digital technologies, providing external memory, rebuild the human consciousness, in which indirect speech strategies are preferred.
\end{abstract}

Keywords: tactics of speech impact, creative activity of the listener, external memory, implicative forms of speech

"Do you think I'm better than you or are you worse than me?"

"Why is it called a prayer when you talk with God, and when God is talking with you it is it called schizophrenia?"

"Is porridge in the head food for the mind?"

Vital issues

\section{Introduction}

One of the leading tasks of communicative practice is-persuasion. Since the time of classical rhetoric, there have been distinguished categories by which persuasion is realized in specific messages.

There are three such categories: Logos, Ethos, Pathos. The concept of logos implies means of persuasion that appeal to the mind. The concept of ethos refers to the means of persuasion, appealing to the norms of human behavior, including speech behavior. It is considered that the speakers' personal ethical qualities determine the entire content of their message and that listeners always have the opportunity to get an idea of what the speaker's ethos is. In many respects, they evaluate their message depending on this.

The concept of pathos is related to the means of persuasion -appealing to the senses. The essence of pathos is that the speaker should be able to arouse feelings in the audience that could affect their opinion.

Rhetoric, as a discipline about speech expediency, otherwise, about conscious "speaking" and correct speech production, posed the problem of choosing the tactics of speech circulation before the creator of the text. And it managed to spot the main regular pattern of human thinking described by science only in the 20th century. This pattern consists in the fact that human thinking is "two-hemisphere", that is, it is the result of a complex interaction of two parts that are corresponded to each other. Moreover, the "language" of one hemisphere is, in principle, not translatable into the "language" of the other. However, since these "languages" coexist as a whole, the exchange between them, nevertheless, takes place.

This exchange is the process of establishing equivalences, which in the acts of thinking can replace each other. The translation of an image into a concept and vice versa is an act of not just thinking, but an act of creativity, here and now, in a specific speech situation. The speaker always has a choice: what should be guided in the construction of the utterance. This is the question of the appropriateness of speech impact and the persuasiveness of speech.

The third section of the rhetorical canon - Elocution - is precisely devoted to the discussion of the issue of how different tactics of speech behavior lead to speech success. It is argued that with an abundance of specific speech tactics, all of their combinations can be correlated with one of two kinds: direct tactics of speech impact and indirect tactics of speech influence. In this article, we are concerned with indirect tactics of speech exposure and the scope of their successful application.

\section{Method}

It is well known that the word "argumentation" is translated from Greek as proof. However, any proof is not an isolated act ("Everything should be perfect in a person: a face, clothes, a soul, and thoughts," as Anton Chekhov 
claimed), but a complex process, in the implementation of which one is guided by a well-defined, logical operation developed in rhetoric with much detail, which is a combination of judgments (conclusions) - elements of a proof. There are three main elements of the proof: thesis, argument, demonstration. We shall initiate our research with demonstration.

\section{Results}

Direct tactics of speech impact are open tactics. It is assumed that with open tactics a speaker imparts to a hearer simply and directly what they mean. J. Searle noted the following about such kind of speech tactics:"The simplest cases of meaning are those in which the speaker utters a sentence and means exactly and literally what he says. In such cases the speaker intends to produce a certain illocutionary effect in the hearer, and he intends to produce this effect by getting the hearer to recognize this intention to produce it, and he intends to get the hearer to recognize this intention in virtue of the hearer's knowledge of the rules that govern the utterance of the sentence. But notoriously, not all cases of meaning are that simple: In hints, insinuations, irony, and metaphor-to mention a few examples - the speaker's utterance meaning and the sentence meaning come apart in various ways..." (Searle, 1975, p. 59).

Direct utterances, apparently, can be considered "the simplest" in the sense that they can hardly be modified. Once and for all, the form found is preserved not because it is appropriate or appears to be such, but because it cannot be different: the direct meanings of linguistic units cannot be varied.

Indirect speech acts is another matter. Indirect tactics of speech impact are intriguing tactics, the tactics that include the listener in the message, taking into account his personal characteristics. An obvious feature of indirect implicative speech tactics is that they provide the listener with "freedom of action," like freedom of initiative and freedom of fantasy. For "to solve" means to analyze, it means sorting out several unsuitable "guesses" in one's mind, to understand why they are unsuitable, and, in the end, to come to a "right decision".

If we are not looking for a recipient in the listener who assimilates "exactly as much" as we intend to transmit, and we transfer to him in the quality we need. If we are interested in a listener-interlocutor who is capable of "on the go" processing information into a "useful product", even by denying, perhaps, the settings most dear to us, indirect tactics turn out to be the most effective. "Show trust only to those who have the courage to argue with you, who prefer your good name to your graces," - these words belong to Catherine II and in our opinion they seem to accurately determine the type of ideal relationship between partners in verbal communication.

Here are two counterexamples of speech strategies. The XIXth century. In a letter to his friend and hostess of the famous literary salon Louise Colet of December 17, 1852, Flaubert wrote that he had returned to his previous plan, that is, to compile «The Lexicon». According to the author, "they will find there in alphabetical order everything that needs to be said in society in order to pass for a decent person ..." (Flaubert, 1984). In «The Lexicon of Common Truths» Gustave Flaubert described in ironic tones his rejection of narrow-mindedness of a bourgeois who does not have his own opinions, but repeats hackneyed and prepared expressions on all occasions. The epigraph to Flaubert's Lexicon was Champhor's dictum: "There is no doubt that any general thought, any universally recognized convention is nonsense, for they are the property of the majority." Here are examples from the Lexicon:

\section{"Fool}

- Anyone who thinks differently

\section{Health}

- Diseases arise from its excess,

\section{Italians}

- All are musicians and traitors.

\section{Critic}

- Always outstanding.

- It is believed that he knows everything, is aware of everything, read everything, saw everything.

- If you do not like him, call him Aristarchus (or eunuch).

\section{Literature}

- Occupation of the idle.

\section{Minister}


- The highest degree of human glory.

Original

- Laugh at everything original, hate it, scold and, if possible, exterminate.

University

- Alma mater.

Scientists

- Mock them.

- To be a scientist, you only need memory and perseverance.

\section{Honesty}

- Inherent mainly in bureaucracy.

\section{Egg}

The starting point for a philosophical dissertation on the origin of the creature. (Flaubert, 1989).

The digital society has changed the demand for communication strategies. As Voiskunsky noted, digital technologies are more than a means of cultural mediation: they provide external memory, which not only adds to the natural and cultural memory, but also decisively rebuilds, restructures human consciousness, forcing it to act in a new way."They enhance the perceptual abilities of humans (eg, by bionic prostheses) and humanity (offering support for new, evolutionarily unformed channels of perception); they open up the possibility of a different way to plan and carry out mental activity, to form and realize the goals that previously seemed unattainable; involve an unlimited number of competent and having their own opinions experts distributed around the world in discussion and realization of such a perspective" (Voiskunsky, 2016, p.9).

The XXth century. World terminology has been enriched by a new concept - sapiosexual - a person who is excited only by very smart people.Woody Allen's story "The Whore of Mensa", in which the character "cheats" on his wife with intellectuals from a "brothel", secretly running from his family to dissolute gold medalists to discuss Eliot and Dante for money could become a manifesto of sapiosexuals. They are those whom highly intellectual conversations excite more than languid looks, frank neckline or strong muscles tearing shirts. Those for whom the best aphrodisiac is a philosophical argument with foam at the mouth. Who prefers the power of the mind to physical strength, and instead of adult films, enjoys watching lectures on websites. From Woody Allen:

\section{«COLLUSION}

Seconds later, a silky voice answered, and I told her what was on my mind. "I understand you can help me set up an hour of good chat," I said.

"Sure, honey. What do you have in mind?"

"I'd like to discuss Melville."

" 'Moby Dick' or the shorter novels?"

"What's the difference?"

"The price. That's all. Symbolism's extra."

"What'll it run me?"

"Fifty, maybe a hundred for 'Moby Dick.' You want a comparative discussion-Melville and Hawthorne? That could be arranged for a hundred."

"The dough's fine," I told her and gave her the number of a room at the Plaza.

"You want a blonde or a brunette?"

"Surprise me," I said, and hung up (Allen, 1974).

Sex for the intellectual is a clue to indirect messages, deciphering obscurities. This is neo-communicative etiquette. The phrase of the character of the film "Stories", who parted with a sexy beauty because she had skipped the lessons of history and did not know what events had preceded the 1917 revolutio: "What to fuck with you about?", which he pronounces in the end, became almost an aphorism. Here are examples of statements in the spirit of sapiosexual rituals:

- $\quad$ "A true intellectual is a person who thinks a lot about what does not concern him at all. 
- A true intellectual will never say: "As she was a fool, so she is." He will say: "Time has no power over her."

- A true intellectual will never say: "Insert your opinion up your ass!" He will say: "Clothe your judgments in milder forms!"

- A true intellectual will never tell a woman to fuck off. He will wish her a rich personal life.

- A true intellectual will never call another an idiot. He will say: "He has a humanitarian mindset" (The rules of life of a true intellectual (https://xochu-vse-znat.ru/ulybnis/pravila-zhizni-nastoyashhegointelligenta.html).

So, the direct tactics of influencing the listener actually implies a vertical model of speech interaction. The vertical model is the interaction along the line from top to bottom (or from bottom to top). Such a relationship between the speaker and the listener is described as a hierarchically structured communication. Critical attitude to the message is excluded. In other words, the frontal, as they say, formulations entail a completely non-creative perception: creative reactions in situations of this kind are excluded. What is stated directly can only be accepted or rejected. What is formulated indirectly needs to be comprehended. That is why, inviting a listener to act as an interlocutor (that is, forming a horizontal model of the speech situation), we must ensure that he is able to really participate in the "construction" of the message content, and not create the illusion of cooperation, in which one of the "cooperating" parties is virtually deprived of any rights.

Educators and teachers applied creative and direct tactics of influence depending on the situation of interaction. If it was necessary to attract the addressee to reflection, speculating on their actions or behavior, to assess the situation - indirect tactics were used. Thus, in one of the brilliant books on education, the author presents satirical rules on where to start if you want to make children spoiled and sick. And under each rule are examples of parents following this rule.

\section{"How to make children stupid}

Give them slaps when they make a wrong doing.

In one house, the usual punishment for any child's oversight was a couple of weighty slaps. If Kaspar or Jörg did something not at the behest of their parents, the usual threat was: "Wait a minute, I'll give you so many slaps in the face that your hearing and eyesight will forever be lost."

And this threat was not just a threat, and every day at least once was so vigorously carried out that the children often stood stunned for several minutes, especially if their father was beating them. For he had sinewy and strong hands and beat them on the head so that often they could hardly stand on their feet.

Due to such a strong concussion, their brains were gradually disordered. Caspar and Jörg became real fools. Their eyes were bulging, and their mouths were almost always open. Mischievous people constantly scoffed at them - they tried to make them believe in the most ridiculous stories, and then laughed at them when they retold with complete confidence that Constantinople had been taken from the Turks or that Master Friedrich had caught a boggart in Springisen.

Those who enjoy having fools around should bring up their children exactly like this, the effect would be remarkable. Probatum est» (Zalzman, 2007, pp.123-124).

When teaching spontaneous speech in both native and foreign languages, not direct, but indirect tactics are also effective. It is a game in some cases. Though language games, like games in general, have many functions, we will focus on one of them - the "destructive" function of the game. This function of the language game overturns the boundaries of established, familiar forms of use of signs. Ignoring logical laws, a language game establishes other relations between objects of judgment. The specificity of these relations is that:

a) any objects and in any quantity can be compared with each other, that is, put in a relationship of analogy;

b) the objects being compared are mutually correlated (each trope and each figure of speech defines its own correlation model) and are interchangeable.

In other words, language games translate relations between objects of reality into relations between objects of utterance, actually replacing reality with speech reality. This type of substitution imparts a rhetorical function to speech utterances. The game, as the territory of a fantastical, constructed space of creativity, allows us to combine the unconnected, introduces its own rules, permeates spheres, acting as an interpretive, metalanguage area of communicative interventions. Due to language games, a person learns to pass through various spheres of consciousness. Therefore, language games can become an indicator of the development of speech competencies 
in the areas of human experience. The classification and inclusion of language games in the level development of speech abilities, forming the latter, simultaneously acts as an indicator of achievements in speech practices. Spontaneous speech becomes a concomitant phenomenon of mastering such games. It is concomitant, and not specially formed. Nobody knows how to specially formulate such speech so far.

In fact, any of the indirect tactics is not entirely accurate. Possibly this is one of the reasons due to which arts associated with indirect speech tactics gradually dwindle from everyday speech: the art of compliment, the art of hint, the art of joking. The response to the compliment is most often distorted: instead of accepting the compliment as a gift (and the compliment is essentially a gift) and thanking for it, the addressee immediately begins to demand an even larger gift. Here are examples of "gurus"' recommendations of how to reply to compliments:

- And I am also quick-witted.

- And my eyes! Wells of beauty!

- Yes, it's me all over.

- You are the thousandth person telling me how beautiful my eyes are.

- I will soon open a club of admirers of my hair.

- I need to thank my parents for making me so smart and beautiful.

- It's good to hear, and most importantly, very unexpected.

- So special! I've never heard anything like this about me!

- And you definitely are not flattering me? Well, thanks, if you're not kidding.

- You haven't seen me without clothes yet.

- Yeah, I can save the whole world alone!

- I'm so beautiful inside and out.

- Yes, and beauty is terribly mighty! So beware of me.(https://doctorfeel.net/relationship-guy/talk-toguy/otvetity-kompliment.html).

The reaction to the hint is usually just as bizarre: when hinted, it is considered quite usual to ask: "Excuse me, are you hinting at something?" Or: "If I've correctly understood your hint, you had the following on your mind". It is clear that if the speaker answers questions or confirms guesses, the hint as such will cease to be a hint. Art of joking: in response to a joke, (especially often not very successful), the listener takes it for granted, for example, to ask the question: "Sorry, were you joking?" or stating: "I hope it was a joke" and even warning: "I will allow myself to joke", although it's obvious that the joke offered or recommended as such has almost half lost its "charge".

All these are the so-called implicative arts. Under implication in linguistic theories based on rhetoric, it has become customary to understand what is designated in Russian as "subaudition". Hence, the word "implicate" means to subaudit, to have a hidden intention / intent.

It is appropriate to recall here that even Jesus Christ in his sermons used an indirect source of persuasion: he spoke in parables. Direct instruction like "Do so!" can cause an individual to protest and desire to argue with what has been said. The parable does not directly teach anyone. It only contains a certain meaningful story. However, despite this "lightness", the meaning contained in a parable is easily remembered and becomes a life's landmark.

\section{Conclusion}

The hypothesis is that the results and, ultimately, the effectiveness of speech tactics is a direct derivative of the degree of creative activity of the listener. The listener's creative activity is incompatible with blind submission even of the most noble and reliable conception of the speaker.

Indirect tactics of speech production also have disadvantages, as a continuation of their advantages. Thus, the conclusions reached by the listener in this case turn out to be less perceptible, but more interesting. Besides, if direct tactics guarantee all listeners the same result ("tactics are read"), indirect tactics ideally lead each listener to their own result: the tactics are unraveled, but the conclusions reached by different listeners do not completely cover each other. And this is a pretext for a dialogue.

We should just side with Yuri Lotman's assertion that "creative thinking, both in the field of science and in the field of art, has an analogous nature and is based on a fundamentally identical basis - the convergence of objects and concepts outside of the rhetorical situation that are not amenable to convergence." (Lotman, 1992, pp.175- 
176). It follows that the creation of meta-rhetoric turns into a general scientific task and teaching indirect communicative strategies is an objective for forming creative thinking.

This is the situation in communications.

\section{References}

Flaubert, G., Biblioteka, K., Gustave, F., \& Gospozha, B. P. (1989). Leksikonpropisnyhistin. Perevod T. Irinovoj M., Hudozhestvennaya Literatura, pp. 381-412.

Flaubert, G. (1984). literature, iskusstve, pisatel'skom trude. Pis'ma. Stat'i: v 2 tomah. - T. 2. -M.: Hudozhestvennaya literatura, 1984, $503 \mathrm{p}$.

Lotman, Yu. M. (1992). Izbrannye stat'i: v 3 tomah / Yu. M. Lotman. - Tallinn : Aleksandra, 1992-1993. T. 1: Stat'i po semiotike i tipologii kul'tury, 1992, $479 \mathrm{p}$.

Pravila, zhizni nastoyashchego intelligenta. Retrieved from https://xochu-vse-znat.ru/ulybnis/pravila-zhizninastoyashhego-intelligenta.html

Searle, J. R. (1975, online 2012, June). Indirect speech acts. In Syntax and Semantics, 3: Speech Acts, ed. P. Cole \& J. L. Morgan, pp. 59-82. https://doi.org/10.1017/CBO9781139173438.

Vojskunskij, A. E. (2016). Chelovek v cifrovom obshchestve //Cifrovoe obshchestvo kak kul'turno-istoricheskij kontekst razvitiya cheloveka: sbornik nauchnyh statej i materialov mezhdunarodnoj konferencii «Cifrovoe obshchestvo kak kul'turno-istoricheskij kontekst razvitiya cheloveka, 11-13 fevralya 2016, Kolomna/ pod obshch. red. R. V. Ershovoj. - Kolomna: Gosudarstvennyj social'no-gumanitarnyj universitet, 2016, 443 p.

Woody, A. (1974). The Whore ofMensa. Retrieved from http://www.newyorker.com/magazine/1974/12/16/thewhore-of-mensa.

Zal'cmann Kristian Gotthil'f. Knizhka dlya rakov. Knizhka dlya murav'ev. Per. s nem. Izdano Mattiasom Dregerom. M.: Izd. «Rajhl'». $-264 \mathrm{p}$.

Войскунский, А. Е. (2016). Человек в цифровом обществе //Цифровое общество как культурноисторический контекст развития человека: сборник научных статей и материалов международной конференции «Цифровое общество как культурно-исторический контекст развития человека, 11-13 февраля 2016, Коломна/под общ. ред. Р. В. Ершовой. - Коломна: Государственный социальногуманитарный университет.

Зальиманн Кристиан Готтхильф. (2010). Книжка для раков. Книжка для муравьев. Пер. с нем. Издано Маттиасом Дрегером. М.: Изд. «Райхль». 264 с.

Лотман, Ю. М. (1992). Избранные статьи: в 3 томах / Ю. М. Лотман. - Таллинн: Александра, 1992-1993. Т. 1: Статьи по семиотике и типологии культуры. - 1992. - 479.

Правила жизни настоящего интеллигента. Retrieved from https://xochu-vse-znat.ru/ulybnis/pravila-zhizninastoyashhego-intelligenta.html

Флобер, Г. (1984). О литературе, искусстве, писательском труде. Письма. Статьи: в 2 томах. - Т. 2. -М.: Художественная литература. 503 с.

Флобер Гюстав. (1989). Библиотекаклассики. / ГюставФлобер. ГоспожаБовари. Повести. Лексиконпрописныхистин. Перевод Т. ИриновойМ., «Художественная литература». С. 381-412.

\section{Copyrights}

Copyright for this article is retained by the author(s), with first publication rights granted to the journal.

This is an open-access article distributed under the terms and conditions of the Creative Commons Attribution license (http://creativecommons.org/licenses/by/4.0/). 